\title{
Temple and Paradise. Some Remarks on the Dynamics of Sacred Place
}

\author{
AleXANDRU MiHĂILĂ
}

In ancient eastern literature, the creation of the world could be connected to the building of the temple dedicated to the creator deity. Creation and temple-building represented for the ancient mentality an obvious continuity that legitimized the cult itself. A further connection could be drawn between the primeval world and the Temple Mount of Jerusalem. The present paper analyzes the intertwining elements of the temple on the holy mountain and the garden of paradise, the original place of pleasure in the presence of God, taking into account the primeval stories of Ezekiel and Genesis. Some elements of the biblical stories will be discussed as part of the history of traditions. For studying the concept of paradise, the first chapters of the Hebrew Bible are for now to be skipped, because, as it will be assumed, earlier accounts are found in the book of Ezekiel.

Keywords: Temple Mount, paradise, Garden of God, sanctuary, Temple ofJerusalem, Eden, Ezekiel, Genesis, Ugarit, Bible.

\section{The Mountain of Paradise in Ezekiel}

Ezekiel, priest and prophet of YHWH, who was engaged in his prophetic ministry during the Babylonian Exile (593-573 b. Chr.), probably wrote the basic part of his book by himself. There is no reason to doubt that the two passages referring to the image of paradise (Ezek. 28 and 31), in which the author speaks in the first person (28:11 and 31:1), go back to historical Ezekiel himself, except for some minor additions. ${ }^{1}$

In Ezekiel 28:11-19 the lament against the king of Tyre alludes to a primeval myth of expulsion from paradise. There is a notable difference between the Masoretic Text and the Septuagint. ${ }^{2}$ In the Hebrew text, the main character (king/primeval human) is identified with the colossal guard-

\footnotetext{
*Alexandru Mihăilă, Associate Professor for Old Testament Study and Biblical Hebrew, Faculty of Orthodox Theology, University of Bucharest, Bd Iuliu Maniu 152A, bl K, sc B, et 1, ap 46, cod 061116, sector 6, București, alexandru.mihaila@unibuc.ro.

${ }^{1}$ See: Walter Zimmerli, Ezekiel 2: A Commentary on the book of the Prophet Ezekiel, Chapters 25-48, trans. James D. Martin (Philadelphia: Fortress Press, 1983), 81-86.

${ }^{2}$ Hector M. Patmore, Adam, Satan and the King of Tyre: The Interpretation of Ezekiel 28:1119 in Late Antiquity, Jewish and Christian Perspective Series 20 (Leiden / Boston: Brill, 2012), 133-210.
} 


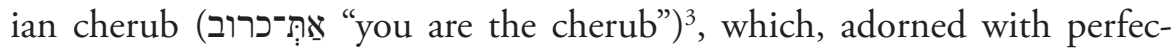
tion and unspeakable beauty, sojourned in Eden, the Garden of God (אלן) אלהים (אלה), surrounded by riches and walking on the holy mountain of God among the stones of fire (28:14). Although the cherub was initially blameless, in the end, sin and violence corrupted his heart through arrogance because of his beauty and wisdom, so that finally he was banished from the mountain of God. In v. 16, כרוב הסכך is understood as a vocative: "O guardian cherub!" This reading was taken over by Jerome's Vulgate ( $t u$ cherub - v. 14; et perdidi te o cherub - v. 16).

On the other hand, in the Septuagint, the king/primeval man is found

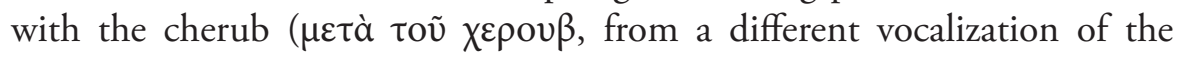
Hebrew Vorlage את־ "with the cherub") and was guarded by him. After wickedness took over the heart of the primeval man, the guardian cherub is

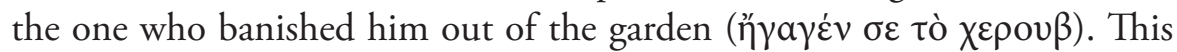

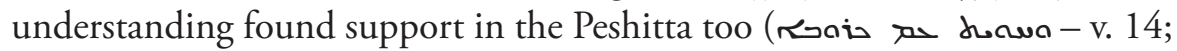

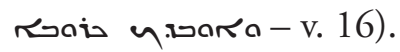

There is no consensus among biblical scholars regarding the original form of the myth. Comparing the two traditions, one can argue that the Septuagint version might be the initial one. ${ }^{4}$ There seems to be no point for a cherub in sinning and being thrown out of the garden. Rather, according to the Septuagint, the primordial man did not know how to appreciate the beauty and perfection with which he was created, he was proud and lost access to the Garden of God. The cherub has been transformed from a protector of man into a guardian of the garden, which is forbidden to man. NRSV, NAB, NET preferred this rendering. On the other hand, the Masoretic version is not without logic either. ${ }^{5}$ In fact in the second paradise

\footnotetext{
${ }^{3}$ Some commentators expect a cherub colossus. Cf. Moshe Greenberg, Ezekiel 20-37: A New Translation with Introduction and Commentary, Anchor Bible 22A (New York: Doubleday, 1997), 579 and 538: "a great shielding cherub" (579).

${ }^{4}$ Zimmerli, Ezekiel 2, 85 and 89; G.A. Cooke, A Critical and Exegetical Commentary on the Book of Ezekiel (Edinburgh: T\&T Clark, 1936), 317-18.

${ }^{5}$ Lydia Lee, "The Tyrian King in MT and LXX Ezekiel 28:12b-15," Religions 12 (2021), art. no. 91 (DOI: https://doi.org/10.3390/rel1202091); idem, "'You Were the (Divine) Cherub': A Potential Challenge to Yhwh's Sole Divinity in Ezekiel 28.14," JSOT 41, no. 1 (2016): 99116; Johan Lust, "The King/Prince of Tyre in Ezekiel 28:11-19 in Hebrew and in Greek," in Textual Criticism and Dead Sea Scrolls Studies in Honour of Julio Trebolle Barrera: Florilegium Complutense, Supplements to the Journal for the Study of Judaism 158, eds. Andrés Piquer Otero and Pablo A. Torijano Morales, (Leiden / Boston: Brill, 2012), 223-34; Hector M. Patmore, "Did the Masoretes Get It Wrong? The Vocalization and Accentuation of Ezekiel XXVIII 12-19," Vetus Testamentum 58, no. 2 (2008): 245-57; Tryggve N.D. Mettinger, The Eden Narrative: A Literary and Religio-Historical Study of Genesis 2-3 (Winona Lake, IN: Eisenbrauns, 2007), 87; Dale Launderville, “Ezekiel's Cherub: A Promising Symbol or a
} 
Temple and Paradise. Some Remarks on the Dynamics of Sacred Place

story in Ezekiel 31, one of the garden trees is expelled and not the primeval man, who is not even mentioned. Albeit a revision of NRSV, ESV chose to follow without any emendation the Masoretic Text.

Nevertheless, the variants don't affect the setting of the story: the scenario developed in the mountain of God (הר קדש אלהים), identified as Eden, the Garden of God (גן־אלהים).

If Walther Zimmerli is right in his analysis that took into account the metrical structure of the lament, the later additions consist in detailing the precious stones (28:13), that remind of the high priest pectoral (Exod. $28: 17-20)$ and in the idea of wisdom (28:12) as part of the original perfection. In the initial form of the poem, Ezekiel doesn't draw his image from Genesis $1-3 .^{6}$

In the Hebrew text, Eden is called "the garden of God": "You were in Eden, the garden of God" (ESV). If Eden is a specific region, as we will see below, then there is no problem of identifying, that for example the Jordan Valley is "like the garden of the Lord" (כגן יהוה) (Gen. 13:10).

There are evident connections with the biblical passages regarding the temple of Jerusalem or the tent of meeting from the time of Exodus. The guardian or the overshadowing cherub (כרוב הסכך) from Ezekiel $(28: 14,16)$ is to be compared to the giant statues of the cherubs from the debir of the Temple of Solomon which overshadowed with their wings the room (ויסכו 1 Kings 8:7) and to the golden cherubs hammered on the cover of the ark with the spreading wings (סככים Exod. 25:20). ${ }^{7}$ Besides these similar elements, there are many similar elements with the story of Genesis (the cherub, cf. Gen. 3:24; Eden; the garden; the richness of metals and precious stones; the initial perfection; expulsion from the garden because of iniquity), but differences worth noting too: 1) the holy mountain (Genesis did

Dangerous Idol?,” Catholic Biblical Quarterly 65, no. 2 (2003): 165-83; James Barr, “Thou Art the Cherub': Ezekiel 28.14 and the Post-Ezekiel Understanding of Genesis 2-3," in Priests, Prophets and Scribes: Essays on the Formation and Heritage of Second Temple Judaism in Honour of Joseph Blenkinsopp, Journal for the Study of the Old Testament Supplement Series 149, eds. Eugene Ulrich, John W. Wright, Robert P. Carroll and Philip R. Davies (Sheffield: JSOT Press, 1992), 213-23.

${ }^{6}$ Daniel I. Block, The Book of Ezekiel: Chapters 25-48 (Grand Rapids, MI: Eerdmans, 1998), 117-18. See: Mettinger, The Eden Narrative, 85-98.

${ }^{7}$ For the role played by cherub, see: D.N. Freedman and M.P. O'Connor, "Kerûb," TDOT, vol. 7, 307-19; Mettinger, "Cherubim", in Dictionary of Deities and Demons in the Bible, eds. Karel van der Toorn, Bob Becking and Pieter W. van der Horst (second extensively revised edition; Leiden, Boston, Köln: Brill; Grand Rapids, MI: Eerdmans, 1999), 189-92; Raanan Eichler, "Cherub: A History of Interpretation," Biblica 96, no. 1 (2015): 26-38; P. Dhorme and L.H. Vincent, "Les Chérubins," Revue Biblique 35, no. 3 (1926): 328-58; "Les Chérubins (suite)," Revue Biblique 35, no. 4 (1926): 481-95. 
not mention the positioning of the garden on height); 2) fire stones, which suggest a supernatural power (stepping through them); 3) iniquity does not consist in disobedience, but in pride for the initial beauty and perfection.

The list of the precious stones from Ezekiel 28:13, reminding the pectoral of the high priest (Exod. 28:17-20 // 39:10-13), suggests that the story might have functioned initially as a story regarding the fall of Jerusalem, the destruction of the temple and the expulsion of the high-priest in 587-586 b.Chr. ${ }^{8}$

The second text of Ezekiel is in chapter 31, which comes mostly from the exilic prophet himself. ${ }^{9}$ This time the king of Egypt (the reference to the king of Assyria might mark a literary stage in the development of the text) is compared to a majestic cedar or cypress (אשאשור instead of (אשור) in Eden, in the garden of God, whose roots lie in great waters, and in the shadow of which all sort of birds find their home. Because of the pride of his heart, but also because of the envy of the other trees in the garden, the cedar was cut down. There are common elements with the Genesis narrative (the primordial river, Eden, the garden, the Tree of Life - in Ezekiel as a giver of life for animals and peoples -; expulsion from the garden because of iniquity), but also differences (resemblance to a cedar, the reason expulsion as envy of others).

The two texts in Ezekiel seem to be writings on the theme of man's creation and loss of the Garden of Eden made before the narrative of Genesis, in other words, they are earlier variants. They show us how present this theme of creation was in the post-exilic period.

\section{Holy Mountain}

Ezekiel's "mountain of God" was expanded by a later redactor to the present expression found in the Masoretic text: "holy mountain of God." To avoid any misunderstanding, the later redactor identifies the mountain of God with the Temple Mount of Jerusalem. But originally Ezekiel played on an old northern tradition about the "mountain of God/gods," referring to Mount Zaphon, ${ }^{10}$ today Jebel al-Aqra', situated at the border between Turkey and Syria, which

\footnotetext{
${ }^{8}$ Bernard Gosse, Structuration des grands ensembles bibliques et intertextualité à l'époque perse. De la rédaction sacerdotale du livre d'Isaïe à la contestation de la Sagesse, Beihefte zur Zeitschrift für die alttestamentliche Wissenschaft 246 (Berlin, New York: Walter de Gruyter, 1997), 43-44.

${ }^{9}$ Leslie C. Allen, Ezekiel 20-48, Word Biblical Commentary 29 (Dallas, TX: Word Book Publisher, 1990), 125. See also: Zimmerli, Ezekiel 2, 148.

${ }^{10}$ Paul M. Joyce, Ezekiel: A Commentary, Library of Hebrew Bible / Old Testament Studies 482 (New York, London: T\&T Clark, 2009), 179. Loren R. Fischer, Duane E. Smith, and Stan Rummel, eds., Ras Shamra Parallels: The Texts from Ugarit and the Hebrew Bible, vol. 2 (Roma: Pontificium Institutum Biblicum, 1975), 318-24.
} 
Temple and Paradise. Some Remarks on the Dynamics of Sacred Place

in the Ugaritic literature was the mountain of the gods in the Canaanite pantheon, similar to mount Olympus for the Greeks. ${ }^{11}$ There is strong evidence in the Hebrew Bible that Mount Zaphon influenced the tradition about Mount Zion in Jerusalem, the Temple Mount. ${ }^{12}$ In Psalm 48:3 Mount Zion paralleled "the heights of Zaphon" (ירכתי צפון). In Hebrew, Zaphon became the standard way for expressing the "north", but this makes sense only for people living nearby south of Mount Zaphon, just as Negeb means for the Judeans "south" or Teman "further south" (see Josh. 15:1; Exod. 26:18).

It seems that the theological transfer from Mount Zaphon to Mount Zion was intermediated by other holy mountains. A possible link in the transition is Mount Bashan (or Mount Hermon?) and in the Northern Kingdom (Israel) Mount Tabor (Ps. 68:16-17). ${ }^{13}$ The reference to Mount Zaphon as the mountain of gods was exported southward as far as northern Egypt, where three different sanctuaries were erected. One of the stations of the people of Israel during the exodus is mentioned, Baal-Zephon (Exod. 14:2, 9; Num. 33:7). ${ }^{14}$

Mount Zaphon is mentioned in the Assyrian annals of Tiglath-pileser III (744-727) ${ }^{15}$ as Ba' 'ali-'apuna (written ${ }^{\mathrm{KUR}} b a$-' $a$-li-șa-pu-na) and the annals of Sargon II (721-705) as Ba'il-Șapuna (written KUR $b a$ - 'i-il-șa-pu-na) ${ }^{16}$. There is an Ugaritic parallel found in $K T U^{3} 1.6 .1 .56-65$ to the myth of the expulsion of a (semi-)divine being from Mount Zaphon, the seat of the head of the Canaanite pantheon, god Baal:

“Thereupon terrible 'Attaru

climbs the heights of Șapānu (Ug. șrrt Ṣpn), sits on Mighty Ba'alu's seat.

(But) his feet do not reach the footstool, his head does not reach the top (of the seat).

\footnotetext{
${ }^{11}$ Richard J. Clifford, The Cosmic Mountain in Canaan and the Old Testament, Harvard Semitic Monographs 4 (Cambridge: Harvard University Press, 1972).

${ }^{12}$ Pace J. de Savignac, "Note sur le sens du terme Sâphôn dans quelques passages de la Bible," Vetus Testamentum 3, no. 1 (1953): 95-96.

${ }^{13}$ Frank-Lothar Hossfeld and Erich Zenger, Psalmen 51-100, Herders Theologischer Kommentar zum Alten Testament (Freiburg, Basel, Wien: Herder, $\left.{ }^{3} 2000\right)$, 253. For Mount Tabor, see: Marvin E. Tate, Psalms 51-100, Word Biblical Commentary 20 (Dallas, TX: Word Books, 1990), 181; Hans-Joachim Kraus, Psalmen. 2. Teilband Psalmen 60-150, Biblischer Kommentar Altes Testament XV/2 (Neukirchen-Vluyn: Neukirchener Verlag, $\left.{ }^{5} 1978\right), 631$.

${ }^{14}$ Paul R. Raabe, "Baal-Zephon," in The Anchor Bible Dictionary, ed. David Noel Freedman, vol. 1 (New York: Doubleday, 1992), 554-55. Cf. the monograph of Otto Eissfeldt, Baal Zaphon, Zeus Kasios und der Durchzug der Israeliten durchs Meer, Beiträge zur Religionsgeschichte des Altertums 1 (Halle: Max Niemeyer Verlag, 1932).

${ }^{15}$ RINAP 1, Tiglath-pileser III 13.6, 30.

${ }^{16}$ RINAP 2, 1.230 and 2.264 .
} 
(To this) terrible 'Attaru responds:

I will not be king of the heights of Șapānu.

Terrible 'Attaru (then) descends,

he descends from the seat of Might $\mathrm{Ba}$ 'alu,

And rules over the earth (Ug. arss), god of it all...". ${ }^{17}$

The minor god Attaru proved himself an imposter as he tried to replace king-god Baal, so he was expelled from Mount Zaphon and established his rule over the earth. The parallel Zaphon / earth (Ug. spn / ars ) is equivalent to the parallel heaven and earth in the Hebrew Bible, or in our case, to the opposite places "mountain of God" and the world outside.

\section{Eden}

For the Sumerians, Edin (EDIN) designates the steppe between the Tigris and Euphrates rivers, known today in Arabic as al-Jazira, where the shepherds grazed their flocks. The cultivated area in the south-east was called "the border of Edin" (GÚ.EDIN.NA), while the highland from the north "upper Edin" (AN.EDIN). ${ }^{18}$ From the Sumerian loanword EDIN, the Akkadian edinu means "desert, steppe,", an equivalent of the Semitic șerrum. ${ }^{19}$

Other scholars claimed that Eden is a derivative from עדן "pleasure," "luxury," 20 even in Ezekiel 28. ${ }^{21}$ In the Old Aramaic inscription (lines 4-5) on the statue of King Hadad-Yith 'i found in Tell Fekheriye (Northern Syria) the expression $m$ 'dn $m t k l n$ is translated into Assyrian as mutahhidu kibräti "who enriches all lands," "who makes all lands abound" or "who provides the whole country with pleasant things." 22 It is fairly supposed that the participle $m$ 'dn stems from a verb 'dn, cognate to Hebrew root עדן "to be soft, lax, pleasant," as old dictionaries rendered it. ${ }^{23}$

\footnotetext{
${ }^{17}$ Manfred Dietrich, Oswald Loretz and Joaquín Sanmartín, Die keilalphabetischen Texte aus Ugarit, Ras Ibn Hani und anderen Orten, dritte, erweiterte Auflage, Alter Orient und Altes Testament 360/1 (Münster: Ugarit-Verlag, 2013), 28; William W. Hallo and K. Lawson Younger jr. (eds.), Context of Scripture, vol. 1: Canonical Compositions from the Biblical World (Leiden / New York / Köln: Brill, 1997), 269-270.

${ }^{18}$ G. Castellino, „Les origines de la civilisation selon les textes bibliques et les textes cuneiformes," in Volume du Congrès, Strasbourg 1956, Supplements to Vetus Testamentum 4, ed. Pieter Arie Hendrik de Boer (Leiden: Brill, 1957), 116-36 (here 122).

${ }^{19} C A D$, vol. p. 33, sub voce edinu.

${ }^{20}$ A.R. Millard, “The Etymology of Eden,” Vetus Testamentum 34, no. 1 (1984): 103-06.

${ }^{21}$ Greenberg, Ezekiel 20-37, 581.

${ }^{22}$ Douglas M. Gropp and Theodore J. Lewis, "Notes on Some Problems in the Aramaic Text of the Hadd-Yith 'i Bilingual”, BASOR 259 (1985), 45-61 (here 45).

${ }^{23}$ See: Gesenius, english edition, 608-609. More nuanced in $B D B, 726-727$, where three different roots עדן are distinguished.
} 
But Eden seems to be a certain place, a region, or a district. In the book of Ezekiel Eden is mentioned in other passages without any connection to the primeval story. ${ }^{24}$ In Ezekiel 27:23, Eden appears together with Haran and Canneh as a region or a place in Upper Mesopotamia and in Ezekiel 31:9, 16, 18 there is a reference to the "trees of Eden." ${ }^{25}$ Eden is an abbreviation from Bet-Eden (Bit-Adini). ${ }^{26}$ In Amos 1.5 the standard form Bet-Eden appears, while in 2 Kings 19:12 (// Isa. 37:12) the designation of the people of Bet-Eden as "sons of Eden" (בני עדן).

Therefore, it is very probable that Eden refers to an Aramean state that lay on the Euphrate, between rivers Euphrate and Balikh. ${ }^{27}$ It was mentioned in the annals of Ashurnasirpal II and Sennacherib as Bit-Adini "house of Adini (or Adinu)" (with 17 occurrences, written É-a-di-ni, É- ${ }^{\mathrm{m}} \boldsymbol{a}$-di-ni, ${ }^{\mathrm{K} U R}{ }^{\mathrm{E}}-$ $a-d i-n i$ and $\left.{ }^{\mathrm{KUR}} \mathrm{E}-{ }^{\mathrm{m}} a-d i-n i\right)$. The country appears as mat mar-Adini "the land of the son of Adini" (written KUR DUMU-a-di-ni) or simply "the son of Adini" (47 occurrences, written DUMU-a-di-ni, DUMU- ${ }^{m} a-d i-n i$ or A- ${ }^{m} a-$ di-ni) already from the reign of Adad-nerari II (911-891), ${ }^{28}$ Ashurnasirpal II $(883-859)^{29}$ and especially Shalmaneser III (858-824). ${ }^{30}$ In 856 b.Chr. it was conquered by King Shalmaneser III. ${ }^{31}$

Interestingly, the Assyrians consider Adini (or Adinu) as a male character, perhaps the founder of the state, because sometimes they used the determinative $I(\mathrm{~m})$ for male persons. This phenomenon is similar to the Assyrian term Bit-Humria "house of Omri," used in Assyrian annals in the same period for the Northern Kingdom, Israel, although it was no more ruled by kings descended from Omri. The spelling Adini might be the genitive so that the nominative would be Adinu, just as the name of the king of Bit-Adini in the times of Ashurnasirpal II and Shalmaneser III was spelled Ahuni, but also Ahunu.

The location of the Eden in Syria is attested as one of the three variants in the Talmud, the other two being Arabia and the land of Israel: "As to the

\footnotetext{
${ }^{24}$ Marius Terblanche, "A Sign to the Reader: The Proper Name עדן in the Book of Ezekiel," OTE 18, no. 1 (2005): 124-34.

${ }^{25}$ Zimmerli, Ezekiel, vol. 2: 92.

${ }^{26}$ Daniel I. Block, The Book of Ezekiel: Chapters 25-48, New International Commentary of the Old Testament (Grand Rapids, MI, Cambridge: Eerdmans, 1998), 79.

${ }^{27}$ André Lemaire, "Le pays d'Eden et le Bît-Adini aux origines d'un mythe," Syria 58, no. 3-4, (1981): 313-30.

${ }^{28}$ RIMA 2, A.0.99.2.48 (p. 150).

${ }^{29}$ RIMA 2, A.0.101.1.iii.42 (p. 215) etc.

${ }^{30}$ RIMA 3, A.0.102.1.43 (p. 9) etc.

${ }^{31}$ Trevor Bryce, The World of the Neo-Hittite Kingdoms: A Political and Military History (Oxford, New York: Oxford University Press, 2012), 168-69.
} 
Garden of Eden - said R. Simeon b. Laqish, "If it is in the Land of Israel, it is Beth Shean where its gate is located; if it is in Arabia, its gate is at Bet Gerem; if it is in Mesopotamia, the gate is at Damascus." (Babylonian Talmud, 'Erubin 19A). ${ }^{32}$ The tradition of association the garden of Eden with Syria and Damascus may be traced even later in medieval Christian exegesis. ${ }^{33}$

In the present Masoretic text, the vocalization of Eden as a region in Syria (עָ עִ עִ with segol) was separated from the passages where Eden refers to the primeval place (עָ with tzere), but this difference reflects a later stage. In the previous consonantal text, such a separation was not possible and, in my view, was not even intended. The West Semitic root עדן "to be pleasant," attested in the Bible, served as a pun for the name Bit-Adini (Bet-Eden).

\section{The Garden}

Hebrew term גן could refer to a garden of vegetables (גן ירק) (Deut. 11:10; 1 Kings 21:2) or a park, a garden with fruit trees (Song of Sol. 4:16; 5:1) or with flowers (Song of Sol. 6:2). Some tombs could be placed in gardens, for example starting with Manasseh the kings of Judah are no longer buried in the royal necropolis, but in the garden of Uzza (2 Kings 21:18) ${ }^{34}$. Valuable to orientals, the garden, like the fountain, was generally fenced and locked (cf. Song. 4.12). The king himself had a garden in Jerusalem (2 Kings 25:4; Jer. 39:4; 52:7), the location of which was known even in the time of Nehemiah (Neh. 3:15), long after the Jewish monarchy had ceased to exist. In the Genesis context, the image of a garden with trees should be preferred. ${ }^{35}$

The origin of this peculiarity of the primeval stories might be found in the royal gardens of the Ancient Near East, ${ }^{36}$ especially in those from the Neo-Assyrian palaces. ${ }^{37}$ In his new capital Kalhu (Nimrud) King

\footnotetext{
32 Jacob Neusner, The Babylonian Talmud: A Translation and Commentary, vol. 3 (Peabody, MA: Hendrickson Publishers, 2011), 95.

${ }^{33}$ See for example St Anthimos the Ivirite, in his manuscript (written in 1709) entitled The characters of the Old and New Testaments (Romanian edition: Sf. Antim Ivireanul, Chipurile Vechiului și Noului Testament), talks about the creation of Adam and the placing in the paradise garden, located in Damascus.

${ }^{34}$ S. Yeivin, "The Sepulchers of the Kings of the House of David," JNES 7, no. 1 (1948): 30-45.

${ }^{35}$ Castellino, "Les origines," 122.

${ }^{36}$ Wolfgang Fauth, "Der königliche Gärtner und Jäger im Paradeisos. Beobachtungen zur Rolle des Herrschers in der vorderasiatischen Hortikultur," Persica 8 (1979): 1-53.

${ }^{37}$ Mirko Novák, "The Artificial Paradise: Programme and Ideology of the Royal Gardens," in Sex and gender in the ancient Near East: proceedings of the 47th Rencontre Assyriologique Internationale, Helsinki, July 2-6, 2001, eds. Simo Parpola and Robert M. Whiting, Compte rendu, Rencontre assyriologique internationale [CRRAI] 47 (Helsinki: Neo-Assyrian Text Corpus Project, 2002), 443-60.
} 
Ashurnasirpal II planted a garden of pleasure (kiru șihate), a delightful garden (kiru rišate), irrigated with a canal drawn from the Upper Zab. For this garden, he used seeds of all kinds of trees taken from the foreign lands which he marched into. It is interesting that the first plant mentioned in the list is the cedar, just as the text from the book of Ezekiel, chap. 31: "I dug out a canal from the Upper Zab, cutting through a mountain at its peak, (and) called it Patti-hegalli. I irrigated the meadows of the Tigris (and) planted orchards with all kinds of fruit trees in its environs. [...] In the lands through which I marched and the highlands which I traversed, the trees (and) plants (lit. "seeds") which I saw were: cedar, cypress, šimiššalû, burāšu-juniper, ..., daprānu-juniper, almond, date, ebony, meskannu, olive, șușūnu, oak, tamarisk, dukdu, terebinth and murrānu, mehru, ..., tīiatu, Kanish-oak, haluppu, șadānu, pomegranate, šallūru, fir, ingirašu, pear, quince, fig, grapevines, angašu-pear, șumlalû, titipu, șippūtu, zanzaliqqu, "swamp-apple," hambuququ, nuhurtu, urzinu, and kanaktu. The canal cascades from above into the gardens. Fragrance pervades the walkways. Streams of water (as numerous) as the stars of heaven flow in the pleasure garden ( ${ }^{G I S ̌ K I R I} \mathrm{~K}_{6}$ ș-h $h a-t e$, lit. "garden of laughters"). Pomegranates which are bedecked with clusters like grape vines ... in the garden ... [I,] Ashurnasirpal, in the delightful garden (GIŠKIRI ${ }_{6}$ $r i$-śá-te, lit. "garden of exultation") pick fruit like ... [...]."38

King Sargon II (721-705) extended the garden and transformed it into a veritable botanical garden, kirimähhu, a Sumerian loanword meaning "big garden" (KIRI ${ }_{6}$ MAH). In an inscription chiselled on the human head bull colossus found in Dur-Šarukkin (Khorsabad), he boasted: "I created around it a botanical garden (kirimāhh hu, written GIŠKIRI ${ }_{6}$ MAH-ḩu), a replica of Mount Amanus (tamšil Hamani, written tam-šil KURha-ma-ni), in which were gathered every kind of aromatic plant from the land Hatti (Syria) (and) every type of fruit-bearing mountain tree." ${ }^{39}$ It is interesting to observe that this garden of pleasures imitated the trees of Mount Amanus from Hatti (Syria).

During the reign of Sennacherib (704-681 b.Chr.) this tradition continued: "I planted alongside it (the palace) a botanical garden (kirimähh $h u$, written ${ }^{\mathrm{GIS}} \mathrm{KIRI} \cdot \mathrm{MAH}-h \mathrm{~h} u$ ), a replica of Mount Amanus (tamšil Hamanim, written tam-šil KUR ha-ma-nim), which has all kinds of aromatic plants (and) fruit trees, trees that are the mainstay of the mountains and Chaldea, collected inside it. To plant gardens, I subdivided the meadowland upstream of the city into plots of two pānu each for the citizens of Nineveh and I handed

${ }^{38}$ RIMA 2, A.0.101.30.36-52.

${ }^{39}$ RINAP 2, 9.41-42. 
(them) over to them. To make (those) planted areas luxuriant, I cut with iron picks a canal straight through mountain and valley, from the border of the city Kisiru to the plain of Nineveh. I caused an inexhaustible supply of water to flow there for a distance of one and a half leagues from the Husur River (and) made (it) gush through feeder canals into those gardens." 40 "The incorporation of plants and animals from his entire realm effectively made the garden of Nineveh a microcosm of the empire." 41

A preliminary conclusion may be drawn. Long before Ezekiel, the tradition of a holy mountain of gods found its way to enrich Zion theology, as attested in some psalms (Ps. 48 and 68). On the other hand, the Judahite king's palace near the Temple Mount had a garden (or even gardens?), a pleasant place for pleasure. When Judah was a vassal of the Neo-Assyria empire, Assyrian influences were to be taken for granted, as for example, the prototype of an Assyrian altar built for King Tiglath-pileser III in Damascus, copied under King Ahaz of Judah by Priest Uriah (2 Kings 16:10). It is reasonable to think that not only altar models influence the religious and political life in Judah, but even the luxurious parks planted near the Assyrian palaces. Assyrians' admiration for Syria and its flora concretized in replicas of Syrian mountain ranges (Mount Amanus) with specific plants (cedar, etc.) in the kingly botanical gardens and parks may have been imitated by the Judahite aristocracy as well. Although no garden is mentioned in connection to the Jerusalem temple, the proximity of the king's palace and garden might have influenced the image of the sacred place. Temple and king's palace merged and Prophet Ezekiel seems to be the first source that attests the holy mountain in association with a garden similar to Bet Eden. Even if Bit Adini was not a mountain or a hill country, it was chosen because of the pun with the root signifying "pleasure" or "delight."

\section{The Garden of Paradise in Genesis}

Although initially in the literary criticism Genesis 2:4b ff was dated in the Solomonic period $\left(10^{\text {th }}\right.$ century b.Chr. $),{ }^{42}$ new insights into the biblical text

\footnotetext{
${ }^{40}$ RINAP 3, 1.87-90.

${ }^{41}$ Clifford Mark McCormick, Palace and Temple: A Study of Architectural and Verbal Icons, Beihefte zur Zeitschrift für die alttestamentliche Wissenschaft 313 (Berlin, New York: Walter de Gruyter, 2002), 64-65.

${ }^{42}$ For example, Gerhard von Rad, Das erste Buch Mose. Genesis, Das Alte Testament Deutsch 2/4 (Göttingen: Vandenhoeck \& Ruprecht, ${ }^{9} 1972$ ), 10 (for dating) and 53-56 (for commentary).
} 
ascribe it to a post-exilic lay ${ }^{43}$ or priestly ${ }^{44}$ redactor. If the present reconstruction of the traditional history is accurate, the Genesis story postdates Ezekiel's texts from chap. 28 and 31.

While Ezekiel identified Eden as a whole with the "garden of God" (Ezek. 31:9, 16, 18), the text of Gen. 2:8 states that the garden lies "in" Eden (בעדן), so it would be inferred from the beginning that Eden is a region or land where Paradise is located. This became very transparent in Gen. 2:10, which describes a river which flowed "out of Eden" (מעדן) and watered the garden. Therefore, the garden is only a part of Eden. In the Talmud, this reality is preserved in a passage that tries to approximate the proportions: "Egypt was four hundred parasangs square. Egypt is a sixtieth of Ethiopia, Ethiopia is a sixtieth of the world, the world is a sixtieth of the Garden, the Garden is a sixtieth of Eden, Eden is a sixtieth of Gehenna. So the whole world is comparable to a pot lid in respect to Gehenna." (Babylonian Talmud, Pesahim 94A). ${ }^{45}$

Further in the text of Genesis, the garden and Eden blended into each other in the expression "garden of Eden" (גן־עדן in 2:15; 3:23-24), as if the whole Eden is the Garden. The term was already used (and even coined?) by Ezekiel (Ezek. 28:13; 31:9, 16, 18; 36:35), and became an expression denoting the opposite to wilderness (Joel 2:3). An interesting expression, missing from Genesis 2, is גן־יהוה "garden of Yahweh" (Gen. 13:10; Isa. 51:3) and "garden of God" (Ezek. 28:13; 31:8-9). The identification of Eden by itself with the garden is evident in Isa. 51:3, where 7 is found in parallelism with "garden of Yahweh." 46

In the Septuagint, the term גis rendered as $\pi \alpha \rho a \dot{\delta} \delta \varepsilon \sigma o \varsigma$ "garden," derived from Old Persian paridaida and Avestan Persian pairidaēza "enclosure." The Persian term occurs in Hebrew as a loanword as well, פרדס (Neh. 2.8; Song of Sol. 4:13; Eccles. 2:5), being inherited by the Latin Vulgate as paradisus and becoming the terminus technicus for the primeval garden. ${ }^{47}$

From the context in Genesis, a more suitable translation might be "park," because God has planted "every tree that is pleasant to the sight and

${ }^{43}$ Joseph Blenkinsopp, "A Post-exilic lay source in Genesis 1-11," in Abschied vom Jahwisten. Die Komposition des Hexateuch in der jüngsten Diskussion, eds. Jan Christian Gertz, Konrad Schmid and Markus Witte, Beihefte zur Zeitschrift für die alttestamentliche Wissenschaft 315 (Berlin, New York: Walter de Gruyter, 2002), 49-61.

${ }^{44}$ Erhard Blum, Studien zur Komposition des Pentateuch, Beihefte zur Zeitschrift für die alttestamentliche Wissenschaft 189 (Berlin, New York: Walter de Gruyter, 1990), 291.

${ }^{45}$ Jacob Neusner, The Babylonian Talmud: A Translation and Commentary, vol. 4 (Peabody, MA: Hendrickson Publishers, 2011), 458.

${ }^{46}$ Ulrich Berges, Jesaja 49-54, Herders Theologischer Kommentar zum Alten Testament (Freiburg, Basel, Wien: Herder, 2015), 123.

${ }^{47}$ B. Jacobs-Hornig, "gan”, TDOT, vol. 3: 36. 
good for food" (Gen. 2:9). The Lord himself acted like a king, "walking in the garden in the cool of the day" (Gen. 3:8). It is from this wonderland that the primordial human lived until he was cast out.

\section{River of Paradise}

The attempt to locate Eden from the book of Genesis started from the mention of the four rivers that flowed from the main river. In fact, the four rivers are more confusing than helpful in locating the garden. In addition, the biblical text says that there was a river that was divided into four arms (in Hebrew "heads"). Or, the Tigris and the Euphrates did not spring from the same place, and in antiquity, they had courses that did not meet at all (nowadays, they join into Shatt al-Arab before flowing into the Persian Gulf). The problem is that two of the four are perfectly locatable (Tigris and Euphrates are both found within the boundaries of modern-day Iraq), but the first two, Pishon (Greek Phison) and Gihon are difficult to identify.

Josephus believed that they were the Ganges of India and the Nile (Jewish Antiquities 1.38-39), but the identification is forced. About Pishon the biblical text says that it surrounded the gold-rich country of Havilah. Elsewhere, Havilah appears as a region near Egypt, in the wilderness, where the Ishmaelites and Amalekites lived (Gen. 25:18; 1 Sam. 15:7). About Gihon, the biblical text says that it surrounds the land of Cush, that is, Ethiopia. In this case, Gihon would be the Nile, just as in the Septuagint text of Jer. 2:18, but the problem is that the usual term for the Nile is in the Bible, Ye'or.

The idea that the paradise river is one river that divides into the wellknown Tigris and Euphrates rivers may imply a mythical geography that corresponds to the present one, which is instead fragmented. The paradise was situated in the center of the world. Later in the Hellenistic period, the location of the paradise in the middle of the world is suggested by associating the Jordan and the Nile (emendation of Heb. יאור t) with the four rivers, Pishon, Tigris, Euphrates and Gihon (Ecclus. 24:25-27). ${ }^{48}$ In the Talmud, the paradise river is understood as watering the whole world. "Said R. Joshua b. Levi, "The entire world drinks from the residue of the water of the Garden

\footnotetext{
${ }^{48}$ Frank Ueberschaer, Weisheit aus der Begegnung. Bildung nach dem Buch Ben Sira, Beihefte zur Zeitschrift für die alttestamentliche Wissenschaft 379 (Berlin, New York: Walter de Gruyter, 2007), 224; Johannes Marböck, Weisheit im Wandel. Untersuchungen zur Weisheitstheologie bei Ben Sira, Beihefte zur Zeitschrift für die alttestamentliche Wissenschaft 272 (Berlin, New York: Walter de Gruyter, 1999), 40. See also: Patrick W. Skehan and Alexander A. di Lella, The Wisdom of Ben Sira: A New Translation with Notes, AB 39 (New York: Doubleday, 1987), 330.
} 
of Eden, as it is said, 'And a river went out of Eden and from there it divided into four parts' (Gen. 2:10)." (Babylonian Talmud, Ta 'anit 10A). ${ }^{49}$

On the other hand, because Gihon is the name of the only water spring found in Jerusalem (1 Kings 1:33, 38, 45; 2 Chron. 32:30; 33:14), an attempt was made in the rabbinic tradition to identify Euphrates and Tigris with two wadis near Jerusalem, in the territory of Benjamin..$^{50}$ Even if the identifications do not withstand the critics (Havilah and Cush must be located as well in the Holy Land), the paradise in the middle of the world and the Jerusalem temple as axis mundi seem to join each other. In fact, the fall of Jerusalem under Babylonians was interpreted as an expulsion from the Garden of Eden. ${ }^{51}$

The text of Genesis built further upon the symbol of the king's park. The temple of Jerusalem did not seem to have an adjacent garden or park, but the king's palace has one. If my understanding is correct, in the exilic and post-exilic period, the park near the king's palace merged with the Temple itself as axis mundi and was then extrapolated for the primeval times. The focus on the garden itself became obvious through the importance of the Tree of Life, as a symbol of the whole park of pleasure.

\section{Temple and Paradise}

The relation between temple and paradise starts from the central position of the temple in the creation accounts in the Ancient Near East. ${ }^{52}$ The temple is the cosmic axis or the navel of the world, as, for example, Shechem is called "the navel of the world" (טבור הארץ) (Judg. 9:37), a termen inherited later by Jerusalem (Ezek. 38:12; cf. 5.5). In the rabbinic literature, it is stated that the creation of the world began with Mount Zion: "A Tannaite statement: From it [Shetiyyah] the world was created. Our Mishnah-teaching accords with them who said: Out of Zion the world was created. [...] And sages say, «It

${ }^{49}$ Jacob Neusner, The Babylonian Talmud: A Translation and Commentary, vol. 7A (Peabody, MA: Hendrickson Publishers, 2011), 47.

${ }^{50}$ Marcel Beaudry and Étienne Nodet, "Le Tigre et l'Euphrate en Benjamin," Biblica 79, no.1 (1998): 97-102.

${ }^{51}$ Bernard Gosse, "Les traditions sur Abraham et sur le jardin d'Éden en rapport avec Is 51,2-3 et avec le livre d'Ézéchiel," in Studies in the Book of Genesis: Literature, Redaction and History, Bibliotheca Ephemeridum Theologicarum Lovaniensium 155, ed. A. Wénin (Leuven, Paris, Sterling: Leuven University Press, Uitgeverij Peeters, 2001), 421-27.

${ }^{52}$ John H. Walton, Genesis 1 as Ancient Cosmology (Winona Lake, IN: Eisenbrauns, 2011), 100-19. 
was created from Zion: A Psalm of Asaph, God, God the Lord has spoken... out of Zion, the perfection of the world (Ps. 50:1, 2)»" (Babylonian Talmud, Yoma 54B). ${ }^{53}$ More detail is given by the Tanchuma: "Just as the navel is positioned in the center of the a man, thus is the Land of Israel positioned in the center of the world, as the Bible says, "dwelling at the very navel of the earth» (Ezek. 38:12), and from it the foundation of the world proceeds... And the Temple is in the center of Jerusalem, and the Great Hall is in the center of the Temple, and the Ark is in the center of the Great Hall, and the Foundation Stone is in front of the Ark, and beginning with it the world was put on its foundation" (Tanchuma, Kedoshim 10). In other words, the temple is the "focus" of the universe. ${ }^{54}$

Interestingly, the inner dynamics of the access to the temple are alluded to in the primeval story of paradise. The entrance to the Temple of Jerusalem resembles the cycle of the sun from east to west, while the exit from paradise is in the opposite direction, to the east. God planted the garden of paradise "in Eden, in the east (מקדם)" (Gen. 2:8), where the term "in the east", "eastward," literally "from the east," might be understood as referring to the viewpoint of the narrator, indicating Mesopotamia, ${ }^{55}$ or as referring to the eastern part of the Eden. The "exit" from the garden of paradise, i.e. the expulsion of the primeval couple, is again "at the east" (מקדם) (Gen. 3:24) and the further departure "from the presence of the Lord" after Cain had been cursed by God followed the same direction: in the land of Nod, "east of Eden" (קדמת־עד) (Gen. 4:16).

An additional example came from the cult stand of Taanach (discovered in 1968). ${ }^{56}$ It is obvious that the cult stand represents a temple in miniature, with four registers marking different areas in the sanctuary: a goddess between two lions, two cherubs, the Tree of Life between two

\footnotetext{
${ }^{53}$ Jacob Neusner, The Babylonian Talmud: A Translation and Commentary, vol. 5A (Peabody, MA: Hendrickson Publishers, 2011), 200.

${ }^{54}$ Jon D. Levenson, “The Temple and the World,” Journal of Religion 64, no. 3 (1984): 275 98 (here 283).

${ }^{55}$ Georg Fischer, Genesis 1-11, Herders Theologischer Kommentar zum Alten Testament (Freiburg: Herder, 2018), 188. See also: Gordon J. Wenham, Genesis 1-15, Word Biblical Commentary 1 (Dallas, TX: Word Books Publishers, 1987), 61. Victor P. Hamilton, The Book of Genesis: Chapters 1-17, New International Commentary on the Old Testament (Grand Rapids, MI: Eerdmans, 1990), 160.

${ }^{56}$ Pirhiya Beck, "The Cult-Stands from Taanach: Aspects of the Iconographic Tradition of Early Iron Age Cult Objects in Palestine," in From Nomadism to Monarchy: Archaeological and Historical Aspects of Early Israel, eds. Israel Finkelstein and Nadav Na'aman (Jerusalem: Yad Izhak Ben-Zvi, Israel Exploration Society; Washington: Biblical Archaeology Society, 1994), 352-81.
} 